NASZA DERMATOLOGIA Online OUR DERMATOLOGY Online

Source of Support: Nil

Competing Interests: None

\section{CHONG HAI TAY AND THE SYNDROME WHICH BEARS} HIS NAME

\author{
Ahmad Al Aboud \\ Dermatology Department, King Abdullah Medical City, Makkah, Saudi Arabia \\ Corresponding author: Dr. Ahmad Al Aboud \\ ahmadalaboud@hotmail.com
}

Tay's syndrome, a rare autosomal recessive disorder, characterized by icthyosiform erythroderma, trichothiodystrophy, brittle hair and nails, intellectual impairment, decreased fertility, short stature, progerialike facies and photosensitivity [1-3]. There is no specific treatment for this genetic disorder. However, some authors reported control of ichthyosis in a case of Tay's syndrome by topical application of tazarotene [3].

This syndrome is reported first by, Dr. Tay Chong Hai in Singapore in the year 1969 [4]. Dr Tay reported it in 2 brothers and a sister, with first-cousin parents of Chinese extraction. One of the children had hypogammaglobulinemia, and one died at age 2 months of intestinal obstruction. Erythroderma was particularly striking at birth.

Chong Hai Tay, was born in 1932 (Fig. 1). He is the first Singapore physician to have a disease named for him in the Western medical literature [5]. He authored more than hundred scientific articles. He wrote also poems. He established the National Arthritis Foundation in 1984, and was chairman for 14 years.

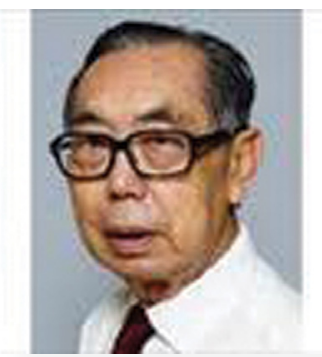

Figure 1. Chong Hai Tay
He is currently in private practice and a consultant physician and rheumatologist at Mt. Elizabeth Hospital, Gleneagles Hospital, Mt. Alvernia Hospital and East Shore Hospital. Dr Tay was the first editor of The Scientific Victorian [5]. Among his many other scientific contributions, he also, reported ten patients who were presenting with acute polyarthritis and hypereosinophilia of unknown causation [6].

\section{REFERENCES}

1. Motley RJ, Finlay AY: A patient with Tay's syndrome. Pediatr Dermatol. 1989;6:202-5.

2. Porto L, Weis R, Schulz C, Reichel P, Lanfermann H, Zanella FE: Tay's syndrome: MRI. Neuroradiology. 2000;42:849-51.

3. Varghese VS, Rai R, Sundaram SV, Prabhu KS, Srinivas CR: Effect of tazarotene on ichthyosiform erythroderma of Tay's syndrome. Indian J Dermatol Venereol Leprol. 2007;73:126-7.

4. Tay CH: Ichthyosiform erythroderma, hair shaft abnormalities, and mental and growth retardation: a new recessive disorder. Arch Derm. 1971;104:4-13.

5. Chong Hai Tay: A page in the internet.Whonamed it. (C) 1994 - 2012 Ole Daniel Enersen. Available online at; http://www. whonamedit.com/doctor.cfm/3120.html

6. Tay C: Eosinophilic arthritis. Rheumatology (Oxford). 1999;38:1188-94.

Copyright by Ahmad Al Aboud. This is an open access article distributed under the terms of the Creative Commons Attribution License, which permits unrestricted use, distribution, and reproduction in any medium, provided the original author and source are credited. 